\title{
Immobilized Lipases: An Old-Fashioned Twist for a New Generation of Industrial Biocatalysts
}

\author{
Nenad Milosavić ${ }^{1 *}$, Jovana Trbojević-Ivić ${ }^{2}$ Dušan Veličković ${ }^{3}$, Aleksandra Dimitrijević ${ }^{4}$ and Dejan Bezbradica ${ }^{5}$ \\ ${ }^{1}$ Department of Medicine, Columbia University, USA \\ ${ }^{2}$ Department of Chemistry, University of Belgrade, Serbia \\ ${ }^{3}$ Department of Biochemistry, University of Belgrade, Serbia \\ ${ }^{4}$ Department of Molecular Biology and Biochemistry, University of California Irvine, USA \\ ${ }^{5}$ Department of Biochemical Engineering and Biotechnology, University of Belgrade, Serbia
}

\section{Introduction}

Lipase catalysed reactions are bio-inspired processes, serving the requirements to integrate environmental welfare with economical demands of modern industry [1]. Microbial lipases are especially prominent industrial biocatalysts with wide array of applications, owing to cost-effective production, pronounced chemo-, regio- and stereoselectivity, high catalytic efficiency in reaction systems with different water content (aqueous solutions to nearly anhydrous systems) and the possibility of tailoring them according to one's need [2-5]. However, their application is often hampered by the lack of longterm stability and difficulties with biocatalyst recovery and recycling.

Elaboration of the right stabilization protocol for lipases is a true work of art, because myriad of opportunities available. Nonetheless, carefully executed immobilization still represents an indispensable tool to improve almost all lipase properties, required for industrial practice [6]. Due to the phenomenon of interfacial activation, lipases are traditionally immobilized on hydrophobic supports, leading to enzyme hyperactivation [7]. Recently, by simple physical adsorption of Candida rugosa lipase (CRL) on hydroxyapatite, a biocompatible biocatalyst with improved thermal stability and excellent stability in methanol was designed, for innovative biosynthesis of short-chain methyl-aroma esters [8]. Two-step covalent immobilization of lipase B from Candida antarctica (CALB) on epoxy-activated Purolite A109 has yielded an immobilized preparation with higher thermal stability compared even with commercial immobilized CALB - Novozyme435 [9]. Similar strategy was implemented for covalent attachment of CRL on Eupergit C, via lipase carbohydrate moiety. As a result, halflife of immobilized CRL at $75^{\circ} \mathrm{C}$ was 18 times higher, compared to free enzyme [10]. By immobilizing CRL, CALB and Rhizopus oryzae lipase in polymer networks, different membrane reactors for hydrolysis of olive oil, synthesis of butyl-butyrate and esterification of lauric acid (respectively) were obtained [11-13]. Extremophylic lipase from Pseudomonas aeruginosa san-ai strain, used in detergents, leather manufacturing and for production of fine chemicals, was immobilized on alginate-type exo-polysaccharide, co-produced and co-secreted with the enzyme [14]. This cost-effective, time-saving approach for simultaneous production, purification and immobilization of lipase, showed a great potential of improving reusability of this enzyme.

Nanoparticles have also emerged as efficient immobilization supports, because of high specific area, effective enzyme loading and resistance to mass transfer effects [15]. Upon immobilization on magnetic cellulose nanocrystals, significant improvements of Pseudomonas cepacia lipase $\mathrm{pH}$, temperature, organic solvent and storage stability were observed. Moreover, the same immobilized enzyme preparation was used for high-yield asymmetric ketoprofenethyl ester hydrolysis [16]. Also, it was revealed that immobilization of CRL on chemically modified silica nanoparticles results with novel biocatalyst with increased thermal stability, operational stability and esterification activity $[17,18]$.
Carrier-free immobilized preparations are relatively new selfassembled systems, based on covalent crosslinking of enzyme molecules in different forms (crystals, aggregates or spray-dried). This proved to be very convenient method for CRL immobilization, giving rise to improved thermal stability and enantioselectivity of immobilized biocatalyst [19].

Constant development in the field of industrial catalysis has given rise to novel applications of lipases as important group of industrial enzymes. Even though it is considered as an old-school technique, immobilization still remains an inexhaustible source of opportunities for making lipases suitable for industrial transformations of a new generation.

\section{References}

1. Gamayurova VS, Shnaider KL, Zaripova SK, Mataz JJ (2016) Enzymatic synthesis of fatty esters by lipase from porcine pancreas. J Thermodyn Catal 7: 161.

2. Gupta S, Bhattacharya A, Murthy CN (2013) Tune to immobilize lipases on polymer membranes: techniques, factors and prospects. Biocatal Agric Biotechnol 2: 171-190.

3. Trbojevic Ivic J, Milosavic N, Dimitrijevic A, Jankulovic MG, Bezbradica D, et al (2017) Synthesis of medium-chain length capsinoids from coconut oil catalyzed by candida rugosa lipases. Food Chem 218: 505-508.

4. Stojanovic M, Carevic M, Mihailovic M, Velickovic D, Dimitrijevic A, et al. (2015) Influence of fatty acid on lipase-catalyzed synthesis of ascorbyl esters and their free radical scavenging capacity. Biotechnol Appl Biochem 62: 458-466.

5. Milisavljevic A, Stojanovic $M$, Carevic $M$, Mihailovic $M$, Velickovic $D$, et al (2014) Lipase-catalyzed esterification of phloridzin: acyl donor effect on enzymatic affinity and antioxidant properties of esters. Ind Eng Chem Res 53 16644-16651.

6. Mateo C, Palomo JM, Fernandez-Lorente G, Guisan JM, FernandezLafuente R (2007) Improvement of enzyme activity, stability and selectivity via immobilization techniques. Enzyme Microb Tech 40: 1451-1463.

7. Fernandez-Lafuente R, Arnisen P, Sabuquillo P, Fernandez-Lorente G, Guisan JM (1998) Immobilization of lipases by selective adsoprtion on hydrophobic supports. Chem Phys Lipids 93: 185-197.

8. Trbojevic Ivic J, Velickovic D, Dimitrijevic A, Bezbradica D, Dragacevic V, et al. (2016) Design of biocompatible immobilized candida rugosa lipase with potential application in food industry. J Sci Food Agr 96: 4281-4287.

*Corresponding author: Nenad Milosavić, Department of Medicine, Columbia University, USA, E-mail: nenadmil@chem.bg.ac.rs

Received December 15, 2016; Accepted December 15, 2016; Published December 22, 2016

Citation: Milosavić N, Trbojević-lvić J, Veličković D, Dimitrijević A, Bezbradica D (2016) Immobilized Lipases: An Old-Fashioned Twist for a New Generation of Industrial Biocatalysts. J Microb Biochem Technol 8: e127. doi:10.4172/19485948.1000 e127

Copyright: (C) 2016 Milosavić N, et al. This is an open-access article distributed under the terms of the Creative Commons Attribution License, which permits unrestricted use, distribution, and reproduction in any medium, provided the original author and source are credited. 
Citation: Milosavić N, Trbojević-Ivić J, Veličković D, Dimitrijević A, Bezbradica D (2016) Immobilized Lipases: An Old-Fashioned Twist for a New Generation of Industrial Biocatalysts. J Microb Biochem Technol 8: e127. doi:10.4172/1948-5948.1000e127

Page 2 of 2

9. Mihailovic M, Stojanovic M, Banjanac K, Carevic M, Prlainovic N, et al. (2014) Immobilization of lipase on epoxy-activated Purolite((R)) A109 and its postimmobilization stabilization. Process Biochem 49: 637-646.

10. Knezevic Z, Milosavic N, Bezbradica D, Jakovljevic Z, Prodanovic R (2006) Immobilization of lipase from Candida rugosa on Eupergit ${ }^{\circledR} \mathrm{C}$ supports by covalent attachment. Biochem Eng J 30: 269-278.

11. Xu J, Wang YJ, Hu Y, Luo GS, Dai YY (2006) Candida rugosa lipase immobilized by a specially designed microstructure in the PVA/PTFE composite membrane. J Membr Sci 281: 410-416.

12. Lozano P, Perez-Marin AB, De Diego T, Gomez D, Paolucci-Jeanjean D, et al. (2002) Active membranes coated with immobilized candida antarctica lipase B: preparation and application for continuous butyl butyrate synthesis in organic media. J Membr Sci 201: 55-64.

13. Goto M, Kawakita H, Uezu K, Tsuneda S, Saito K, et al. (2006) Esterification of lauric acid using lipase immobilized in the micropores of a hollow-fiber membrane. J Am Oil Chem Soc 73: 209-213.

14. Dimitrijevic A, Velickovic D, Rikalovic M, Avramovic N, Milosavic N, et al. (2011) Simultaneous production of exopolysaccharide and lipase from extremophylic
Pseudomonas aeruginosa san-ai strain: A novel approach for lipase immobilization and purification. Carbohydr Polym 83: 1397-1401.

15. Ansari SA, Husain Q (2012) Potential applications of enzymes immobilized on in nano materials: A review. Biotechnol Adv 30: 512-523.

16. Cao SL, Huang YM, Li XH, Xu P, Wu H, et al. (2016) Preparation and characterization of immobilized lipase from pseudomonas cepacia onto magnetic cellulose nanocrystals. Sci Rep: 6.

17. Banjanac K, Mihailovic M, Prlainovic N, Stojanovic M, Carevic M, et al. (2016) Cyanuric chloride functionalized silica nanoparticles for covalent immobilization of lipase. J Chem Technol Biotechnol 91: 439-448.

18. Banjanac K, Mihailović M, Prlainović N, Ćorović M, Carević M, et al. (2016) Epoxy silanization - tool for improvement of silica nanoparticles as support for lipase immobilization with respect to esterification activity. J Chem Technol Biotechnol 91: 2654-2663.

19. Velasco-Lozano S, Lopez-Gallego F, Vazquez-Duhalt R, Mateos-Diaz JC, Guisan JM, et al. (2014) Carrier-free immobilization of lipase from candida rugosa with polyethyleneimines by carboxyl-activated cross-linking. Biomacromolecules 15: 1896-1903. 